\title{
BEHAVIOUR OF TIMBER BEAM STRUCTURES WITH SUSPENDED CEILING WHEN EXPOSED TO FIRE
}

\author{
MARIE RUSINOVÁ*, MILOŠ KALOUSEK, MILOŠ LAVICKÝ \\ Institute of Building Structures, Faculty of Civil Engineering, Brno University of Technology, \\ Veveř́ 95, 60200 Brno, Czech Republic \\ *E-mail: rusinova.m@fce.vutbr.cz
}

\begin{abstract}
Wooden structures are the oldest building elements accompanying man since time immemorial. The Czech Republic is strict in its legal and normative regulations relating to the use of wooden building components. In spite of that the Czech construction market is increasingly returning to wooden houses; not only for dwelling purposes, but also for public amenities. However, the structures made of wood as combustible material have to be carefully assessed especially from the viewpoint of fire safety of the building. This paper deals with the fire safety of wooden structures with special regard to the suspended type of ceiling, as it fulfils the role of insulation against the effects of fire. In particular, the thermal stress caused by fire and its impact upon the safety of the building elements has been investigated.
\end{abstract}

Keywords: wooden structures, wooden ceilings, suspended ceiling, fire safety of buildings, heat stress, fire resistance of structures

\section{Introduction}

Wooden buildings enjoy steadily growing popularity in the Czech Republic, irrespective of the interrupted tradition and of the adoption of very severe legal and normative requirements limiting their utilization. Strict principles are postulated in particular concerning the fire safety of structures. In spite of these obstacles the wooden structures are ever more favoured in the role of construction systems for family houses and in the residential building trade. This trend can be explained especially by their outstanding physical properties, by the quick building process and, last but not least, also by favourable pricing. As mentioned by Bisby [1]: "Timber is amongst the oldest building materials used by humankind. Timber has consistently remained a key structural and building material in most cultures. ... Timber is combustible and presents special fire safety challenges."

Notwithstanding the fact that wood is a burnable material, its behaviour under the effect of high temperatures during a fire can be characterized as satisfactory [2].
Combustibility, strictly speaking, is no clear-cut physical quantity, but rather a sort of description of the behavior of an element or a structure under the effect of high temperatures due to fire. The consequence of impacting high temperatures is seen in provoking a thermo-oxidizing reaction of the wooden element; a thermal decomposition of wooden bonds is seen to take place, along with changes of the chemical and physical properties of the timber structure. There are important milestones of the process of high temperatures affecting wooden elements, namely the inflammation point, the burning point and the ignition point. The inflammation point varies within the range of $180{ }^{\circ} \mathrm{C}$ to $275{ }^{\circ} \mathrm{C}$, which is the interval of temperatures under whose effect a wooden element catches fire when approached by flame, but extinguishes again when the flame is removed. This temperature is not essential for the assessment of a structural element. The decisive temperature to be investigated in our case will be the burning point that lies within the interval from $260{ }^{\circ} \mathrm{C}$ to $290{ }^{\circ} \mathrm{C}$. Under these temperatures a wooden element will catch fire when approached by an external flame, but it will continue

This is an open-access article distributed under the terms of the Creative Commons Attribution-NonCommercial 4.0 International License (https://creativecommons.org/licenses/by-nc/4.0/), which permits unrestricted use, distribution, and reproduction in any medium for non-commercial purposes, provided the original author and source are credited, a link to the CC License is provided, and changes - if any - are indicated. 
to burn when the flame is removed. The temperature that can lead to self-ignition of a wooden element is called inflammability point. It lies within the interval between $330{ }^{\circ} \mathrm{C}$ and $520{ }^{\circ} \mathrm{C}$. Wood is not a homogeneous material and, accordingly, its combustibility is influenced by many factors. The favourable thermal features of wood, its high thermal capacity and low thermal conductivity are the key issues of the good resistance of wooden elements against fire. Further also especially its density, anatomic arrangement and humidity are seen to have positive effects. An important role is played by the surface finishing and by the way the wooden element has been processed. In the described case we will consider hard-wood with humidity under $18 \%$ [3], solid-sawn with carpenter workmanship, free from chemical treatment, such as impregnation against wood worm.

An important indicator for determining the thermal resistance of a wooden element, as well as for determining its residual carrying cross-section, is the depth of carbonization, i.e. the char layer [4].

When analyzing the behavior of structures, with regard to the arrangement of all constructions of the ceiling, we will suppose that the carrying structure gets heated from three sides. Due respect will be paid to the role of the suspended ceiling, as it provides an insulation layer against the impact of high temperatures during the initial phase of the fire, while influencing the overall behavior of the ceiling structure during the course of the fire.

\section{Materials and calculation methods}

This article represents the possibility of predicting the behaviour of three ceiling structures designat-

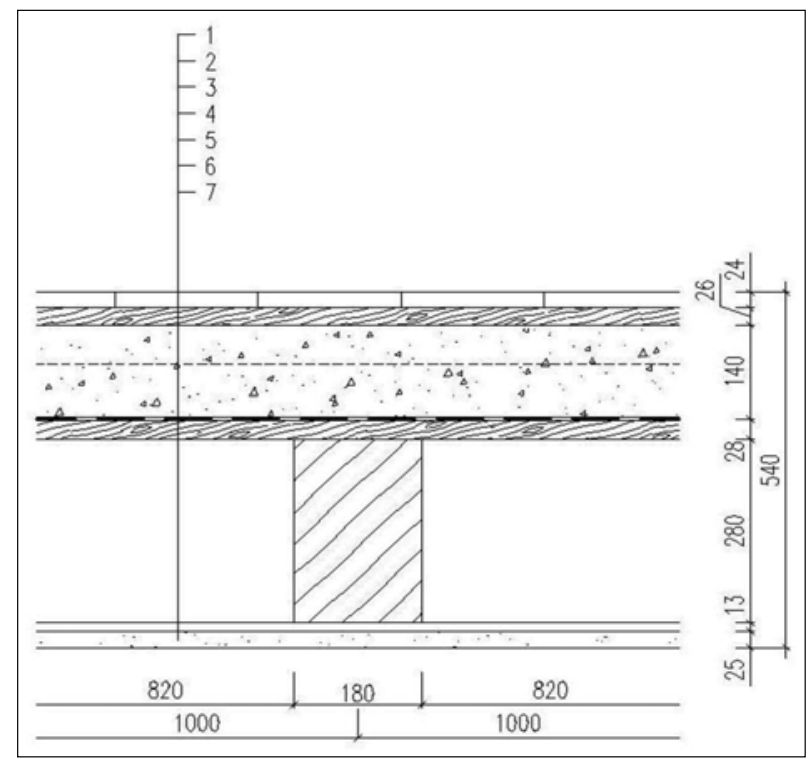

Fig. 1. Timber beam ceiling V1 ed V1 to V3, all of them making use of a timber beam as the carrying element. These ceiling structures with roughly the same loading capacity are exposed to the theoretical impact of high temperatures of a fire conforming to the standard time temperature curve [5].

The first case V1 is a timber beam ceiling of the historical type. Such ceiling structures are encountered in the course of refurbishment projects. The composition above the trusses $180 / 280 \mathrm{~mm}$ with axial distance of 1 metre consists of 1) oak boards $24 \mathrm{~mm}$ thickness, 2) solid-sawn floor of wooden planks $26 \mathrm{~mm}$ thickness supported by cushions (wooden balks $80 / 60 \mathrm{~mm}$ ), 3) rubble fill of $140 \mathrm{~mm}$ thickness, 4) tar paper and 5) decking made of planks $28 \mathrm{~mm}$. The suspended ceiling is created by 6 ) ceiling boarding (thin planks) of $13 \mathrm{~mm}$ and 7) plaster on reed lathing (Fig. 1).

The second case V2 is the same type of timber beam ceiling after refurbishment (Fig. 2). The composition above the trusses $180 / 280 \mathrm{~mm}$ with axial distance of 1 metre is as follows: 1) oak boards $24 \mathrm{~mm}$ thickness, 2) gypsum-fibreboards Fermacell $3 \times 30 \mathrm{~mm}, 3$ ) gypsum-woodfibre boards Steco Isorel $19 \mathrm{~mm}$, 4) Fermacell filling $60 \mathrm{~mm}$, 5) cellular system Fermacell $30 \mathrm{~mm}, 6)$ geotextile layer and 7) decking made of $28 \mathrm{~mm}$ thick planks. An insulating layer of mineral wool (8) reaching to $2 / 3$ of the height of the carrying beam has been deposited on the casing for the purpose of improving the constructional physical properties of the structure, in particular concerning acoustics. The suspended ceiling is created by (9) gypsum-plasterboard $2 \times 12.5 \mathrm{~mm}$ (Fig. 2).

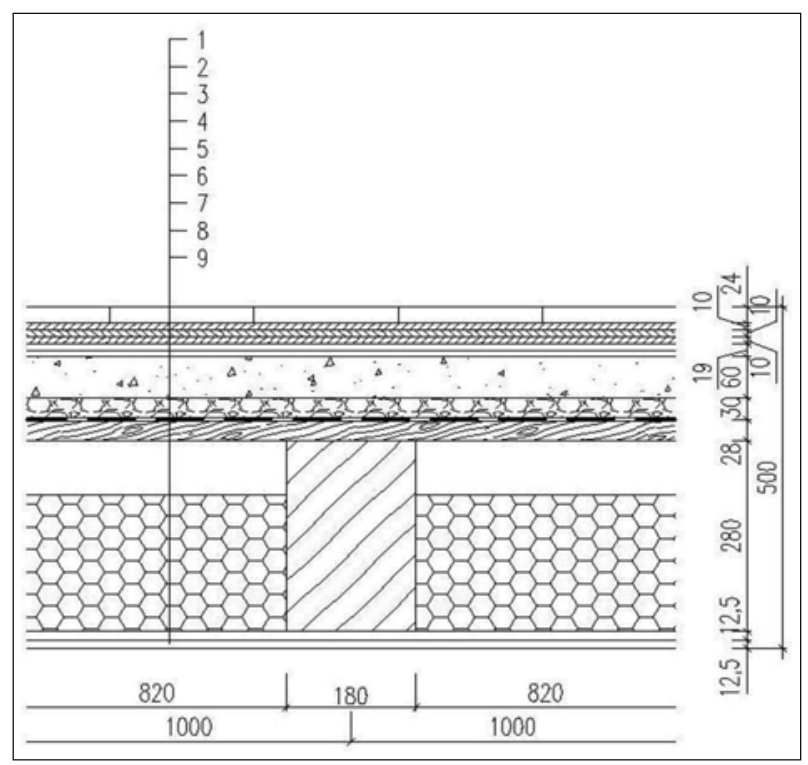

Fig. 2. Timber beam ceiling V2 


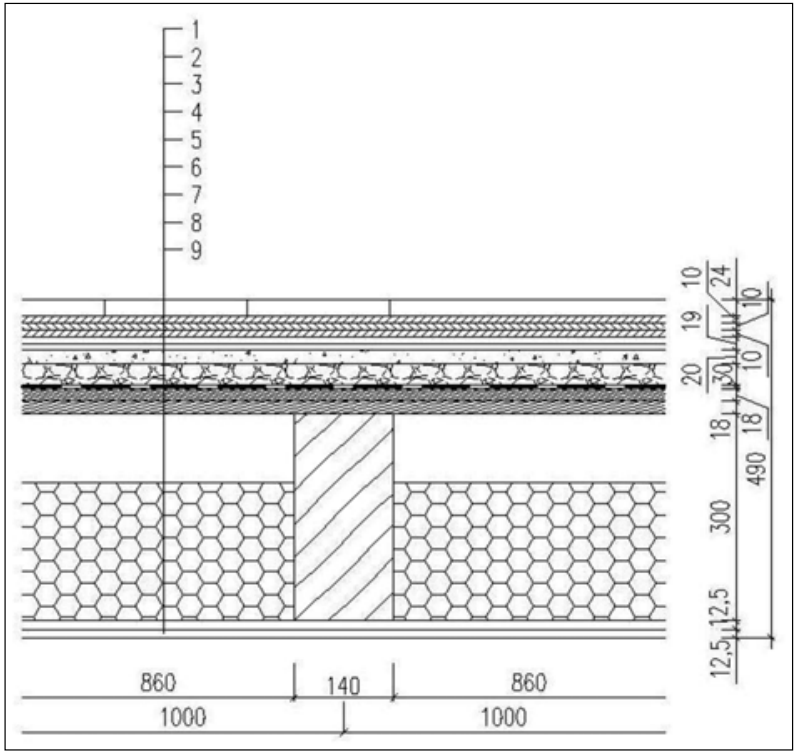

Fig. 3. Timber beam ceiling V3

The last ceiling under consideration $\mathrm{V} 3$ is a newly designed timber ceiling differing from the refurbished one by the dimensions of the beams, namely 140/300 $\mathrm{mm}$, the height of filling, amounting to $20 \mathrm{~mm}$, and the decking made of $2 \times 18 \mathrm{~mm}$ OSB boards (Fig. 3 ).

All investigated timber ceilings have basically the same load carrying capacity. In case of $5.400 \mathrm{~m}$ span the resulting planned utility load amounts to $2 \mathrm{kN} / \mathrm{m}^{2}$ [6-9].

The methodology for predicting the behavior of the examined timber ceilings V1 to V3 was based upon the time dependent technical analysis of each ceiling enabling to determine the $300{ }^{\circ} \mathrm{C}$ isotherm, whereas the static analysis served for the determination of the cross-section characteristics of sections weakened due to layers where pyrolytic effect is anticipated [10].

These three ceiling structures were exposed to theoretical thermal load corresponding to the course of temperatures during a fire, complying with the standard time temperature curve [4] - see Fig. 4, as given by Eq. (1):

$$
\Theta_{g}=20+345 \log (8 t+1),
$$

$\Theta_{g}$ - temperature $\left[{ }^{\circ} \mathrm{C}\right]$ of gases in the fire compartment under consideration;

$t$ - time [min].

The course of thermal stress is based upon the prerequisite that the bottom layers of a timber ceiling function as insulation of the carrying element - the beam - against high temperatures. As concerns ceiling $\mathrm{V} 1$, the termination of the effect of the suspended ceiling was determined by the time required by $300^{\circ} \mathrm{C}$ isotherm to reach half of the thickness of planks creating the carrying element of the suspended ceiling. The suspended ceilings V2 and V3 are created by two gypsum-plasterboard layers. The results obtained by experiment within the research project* in a not standardized test fire oven enabled the finding that a double-layer gypsum-plaster encapsulation stops fulfilling its function when exposed to load according to the standard time temperature curve after the 40th minute of the test, and namely irrespective of the further composition of the tested sandwich structure.

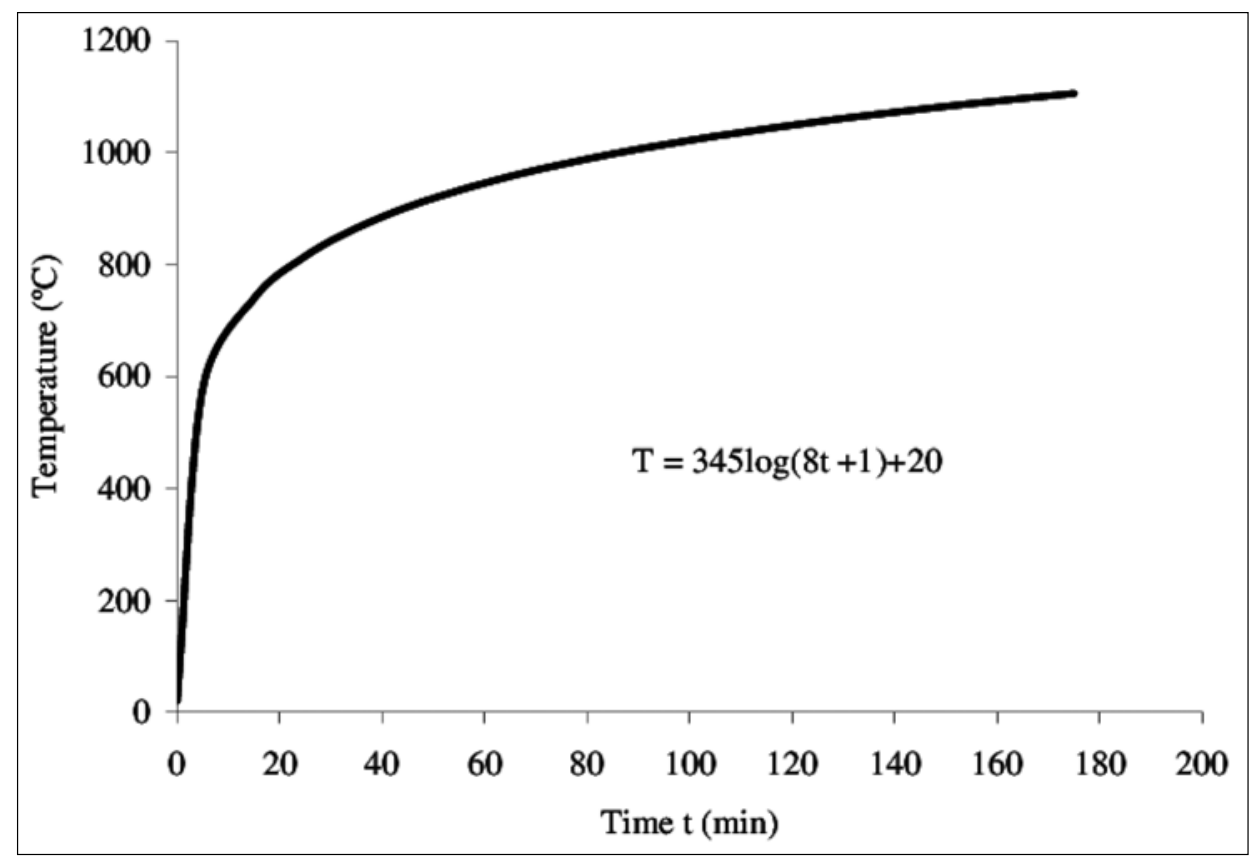

Fig. 4. Time temperature curve ISO 834 [4] 


\section{Results}

The thermal technical analysis for determining the $300{ }^{\circ} \mathrm{C}$ isotherm, indicating the depth of carbonization according to the EC5 [9], was carried out with the help of the ANSYS v14.5 [11] program system by the finite elements method in the Thermal module. Flat four-node elements PLANE55 with $5 \mathrm{~mm}$ edge were used, and the composition of the ceiling was modelled with the utilization of the symmetry axis, and namely from one half only of the axial distance of the beams. The time step was 30 seconds, but due to the utilization of a nonlinear solver, the step was adaptively refined in case of quick temperature changes. The non- linear solver was applied in considering the extensive variance of physical features $(\lambda-$ Thermal Conductivity Coefficient, $\rho-$ Density and $c-$ Heat Capacity) depending upon the temperature reached at a specific point of the given structure and the respective material. As a rule, the values of the thermal conductivity coefficient and of $c$ increase along with rising temperatures in current materials, whereas in this case the carbonization of wood results in their drop, as well as in the decrease of density down to the level of thermal insulating material (such as mineral wool).

The time dependent course of reaching the $300{ }^{\circ} \mathrm{C}$ level in the ceiling structures V1 to V3 are shown in Figs 1 to 3 .
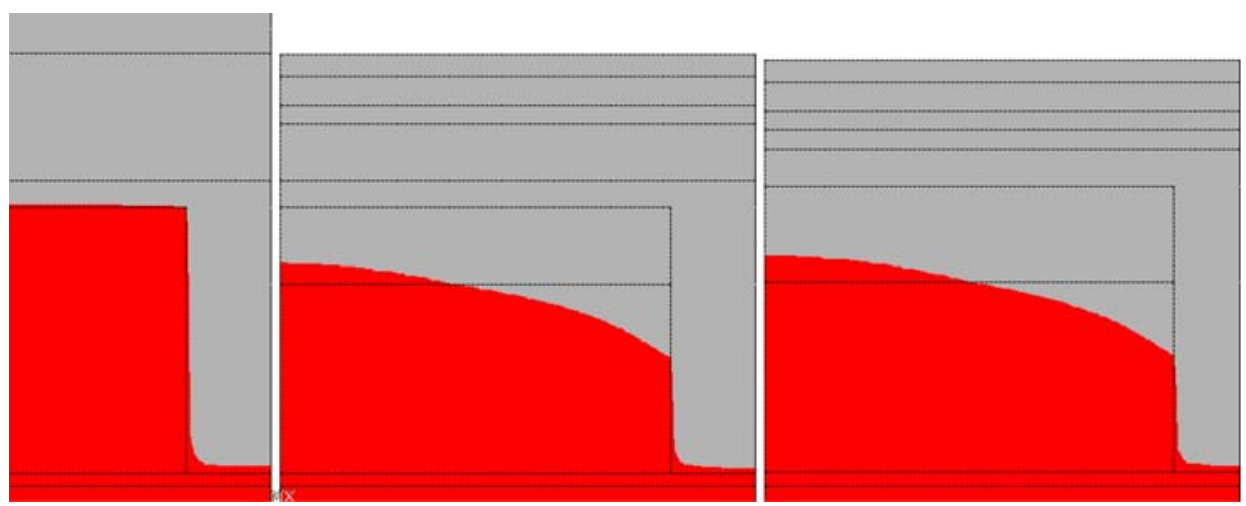

Fig. 5. Reaching $300^{\circ} \mathrm{C}$ and more in ceiling structures within 15 minutes
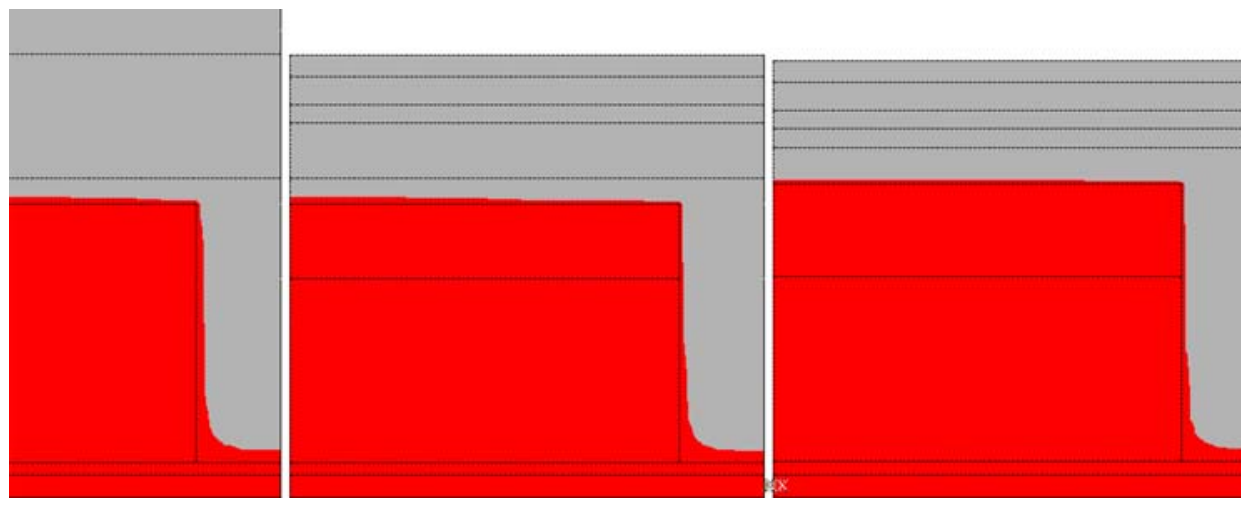

Fig. 6. Reaching $300{ }^{\circ} \mathrm{C}$ and more in ceiling structures within 30 minutes
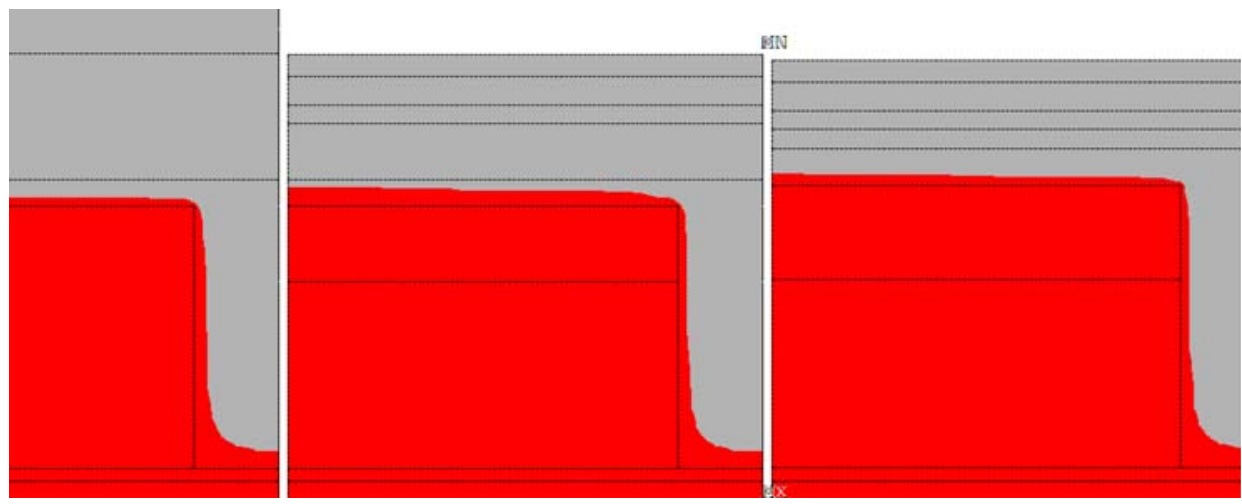

Fig. 7. Reaching $300{ }^{\circ} \mathrm{C}$ and more in ceiling structures within 45 minutes 


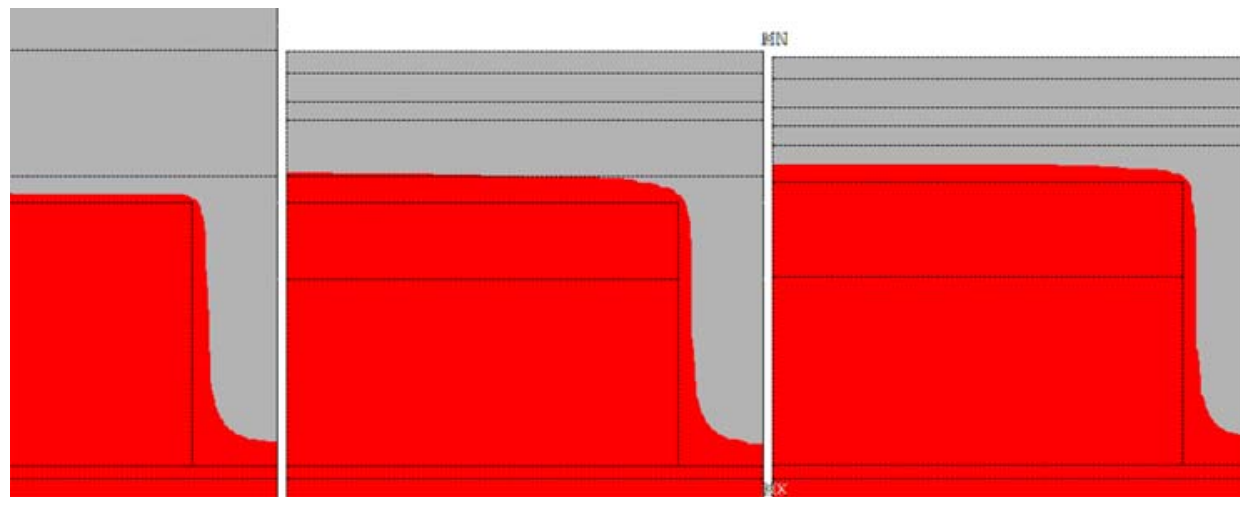

Fig. 8. Reaching $300{ }^{\circ} \mathrm{C}$ and more in ceiling structures within 60 minutes
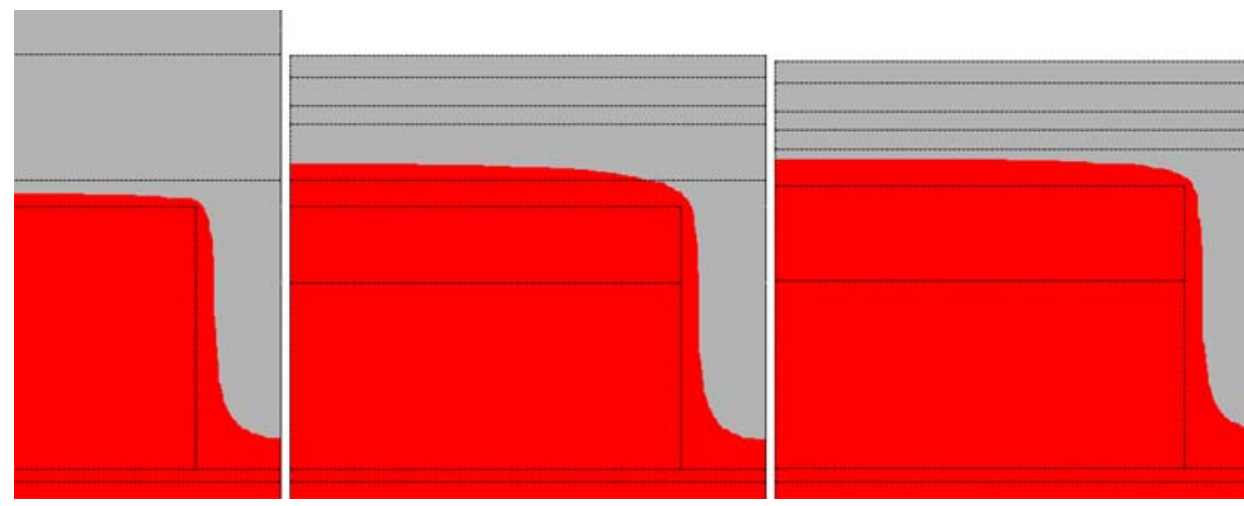

Fig. 9. Reaching $300{ }^{\circ} \mathrm{C}$ and more in ceiling structures within 75 minutes
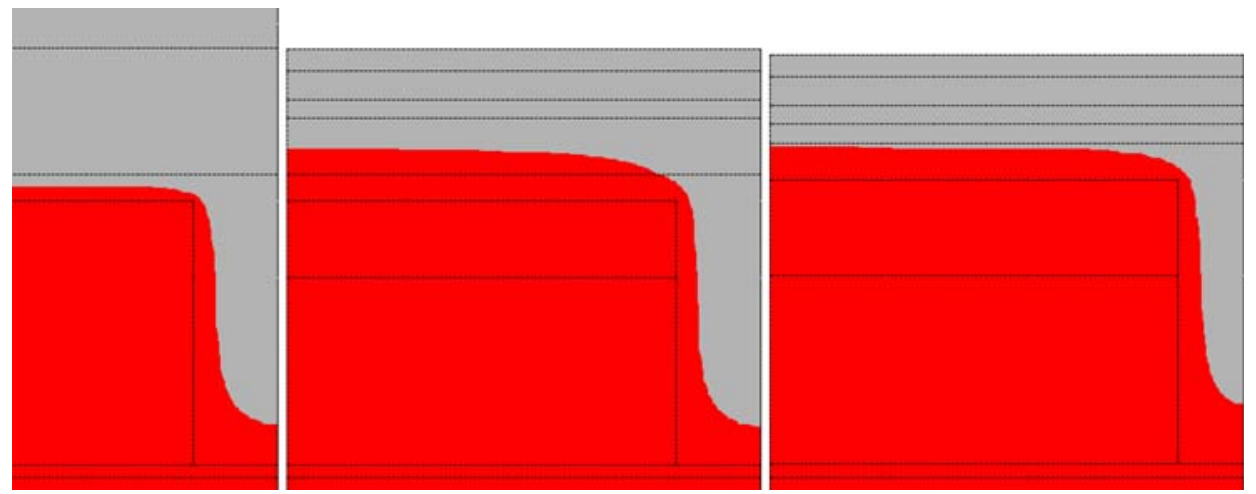

Fig. 10. Reaching $300{ }^{\circ} \mathrm{C}$ and more in ceiling structures within 90 minutes

The static analysis was based upon a certain idealization, namely that the part of the section of a ceiling beam where the temperature of $300{ }^{\circ} \mathrm{C}$ and more was reached cannot be comprised in the calculation as part of the efficient section due to having suffered pyrolytic damage.

This prerequisite is based upon the European standard for structural design of wood EC5 [9], this standard is the main basis for research and calculations of this kind [12]. Then the values of the section modulus and of the moment of inertia were calculated at time nodes for the residual cross-section of the ceiling beam established in this way. The calculation of the residual section for determining the average values took into account the shape and the position of the $300{ }^{\circ} \mathrm{C}$ temperature isotherm.

The decrease of the carrying capacity of the ceiling structure due to the carbonization of the surface layers of timber trusses is given by the changed value of the section modulus in the nodal points of time. Increased sagging depends upon the value of the moment of inertia at the time nodes.

The results are shown in Graph 1 to Graph 2.

\section{Discussion}

The results of the analyses predict the best fire resistance of the ceiling structure V2. The belated access of 


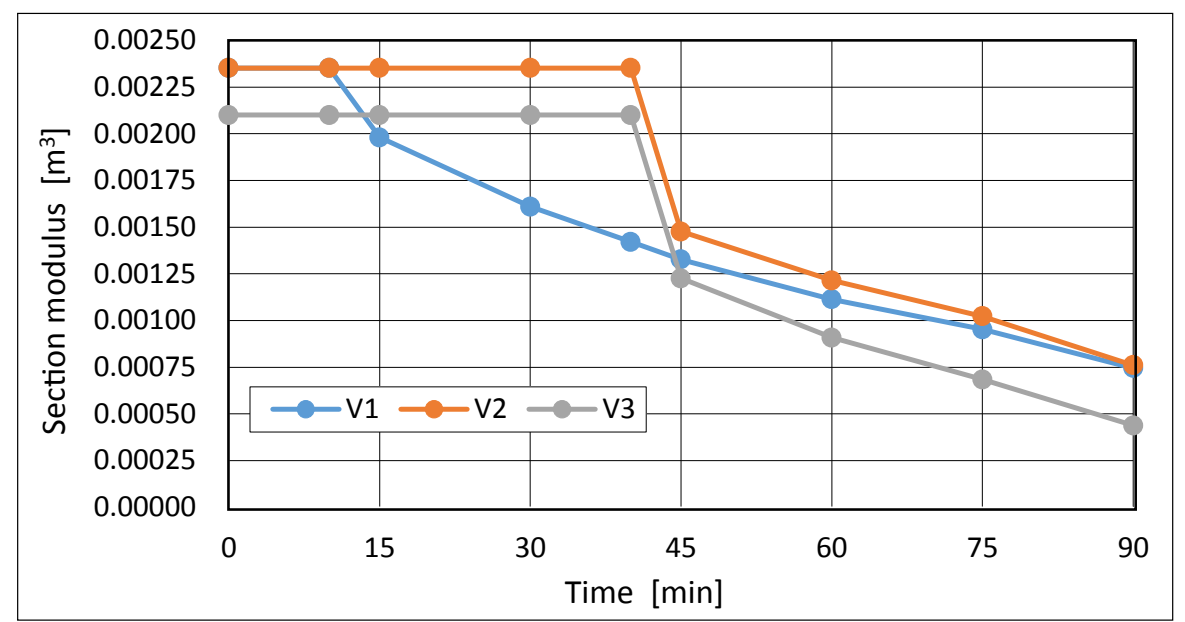

Graph 1. Time dependence of the section modulus (to the bottom fibres)

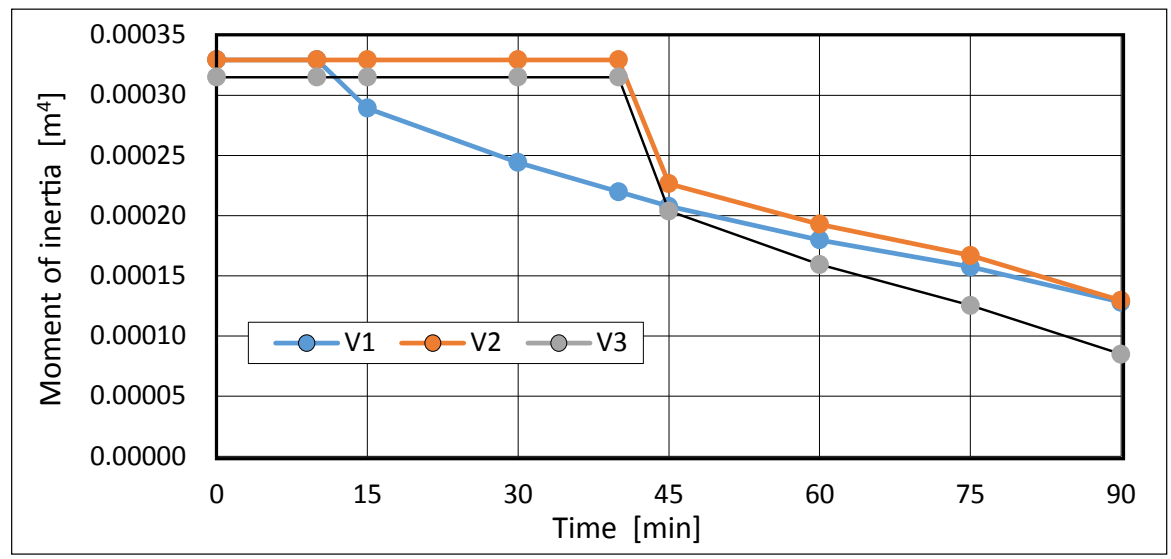

Graph 2. Time dependence of the moment of inertia

flame is due to the higher fire resistance of this suspended ceiling. An interesting result is shown also by the time dependent course of temperature in the ceiling structure V1 where the favourable effect of the thermal accumulation properties of the rubble filling is manifested. The comparison of V3 with the V1 and V2 results indicate how the section width can influence the fire resistance.

It can be noted that the changed characteristics owing to the position of the $300{ }^{\circ} \mathrm{C}$ isotherm were calculated also for the time nodes which the structure does not reach at all during the fire resistance testing, since the ceiling can collapse otherwise than due to loss of carrying capacity of the beam, e.g. due to the burning through of the decking, or it does not withstand the imposed testing load. One of the problems to be solved is the time gap between reaching the $300{ }^{\circ} \mathrm{C}$ temperature and the ability of the heated layer of wood to bear stress.

\section{Conclusion}

The represented methodology has not the power of evidence of a fire test, but it can serve for estimating the behaviour of structures under fire. In the course of elaborating the described task a number of further problems appeared that deserve future attention.

\section{Acknowledgements}

This paper has been worked out under the Research Project* MPO FV10075 "New Technology of Multistorey Energy-efficient Buildings Made of Structural Insulated Panels with Possibility of Ground Screw Foundations and with Usage of Prefabricated Service Core Technology, EUROPANEL ${ }^{\mathcal{C}}$ ".

\section{References}

[1] Bisby L. A., Frangi A. (2015), Fire Technol, 51, 1275. https://doi.org/10.1007/s10694-015-0539-1 = special Issues.

[2] Kuklík P., Kuklíkova A, (2010), Navrhování dřevěných konstrukcí. Příručka k ČSN EN 1995 - 1 (Design of timber structures. Handbook of ČSN EN 1995-1), 140 p., Praha.

[3] Information on https://stavba.tzb-info.cz/drevostavby/5455montovane-nosne-konstrukce-drevene-konstrukce.

[4] ISO 834-10 (2014), Fire resistance tests - Elements of building construction. 
[5] Hurley M. J. (2016), SFPE Handbook of Fire Protection Engineering. Springer Science+Business Media, LLC New York.

[6] ČSN EN 1990 (73 1002) (2004), Eurokód: Zásady navrhování (Eurocode: Basis of structural design).

[7] ČSN EN 1991-1-1 (73 0035) (2004), Eurokód 1: Zatížení konstrukcí - Část 1-1: Obecná zatížení - Objemové tíhy, vlastní tíha a užitná zatížení pozemních staveb (Eurocode 1: Actions on structures - Part 1-1: General actions - Densities, self-weight, imposed loads for buildings).

[8] ČSN EN 1995-1-1 (73 1701) (2007), Eurokód 5: Navrhování dřevěných konstrukcí - Č́st 1-1: Obecná pravidla - Společná pravidla a pravidla pro pozemní stavby (Eurocode 5: Design of timber structures - Part 1-1: General - Common rules and rules for buildings).
[9] ČSN EN 1995-1-2 (73 1701) (2007), Eurokód 5: Navrhování dřevěných konstrukcí - Část 1-2: Obecná pravidla - Navrhování konstrukcí na účinky požáru (Eurocode 5: Design of timber structures - Part 1-2: General - Structural fire design).

[10] White R. H., Woeste F. E. (2013), Post-Fire Analysis of Solid-Sawn Heavy Timber Beams. Structure Magazine, pp. 38-40, November 2013.

[11] Manual, Ansys, Inc. 2016.

[12] Leško R., Lopušniak M. (2015), Fire resistance of timber elements and structures in multi-storey building determined by eurocode 5. Acta Facultatis Xylologiae, 57(2), 135-144. 